\section{城市儿童空间设计中的认知科学 THE COGNITIVE SCIENCE OF URBAN SPACE DESIGN FOR CHILDREN}

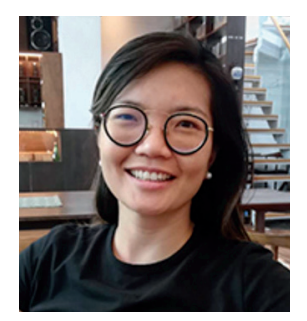

斯黛拉 · 克里斯蒂

清华大学心理学系副教授、清华大学脑与智能实验室首席研究员, 清华大学脑与智能实验室儿童认知研究中心主任

\section{Stella CHRISTIE*}

Associate Professor of Department of Psychology, Tsinghua University; Research Chair of Tsinghua Laboratory of Brain and Intelligence; Director of Child Cognition Center of Tsinghua Laboratory of Brain and Intelligence

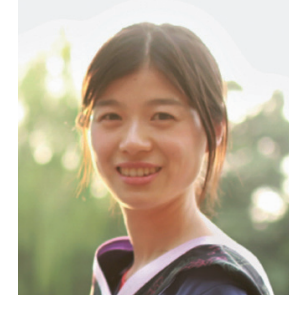

吕金云

清华大学脑与智能实验室儿童认知研究中心管理员

\section{LYU Jinyun}

Lab Manager of Child Cognition Center of Tsinghua Laboratory of Brain and Intelligence

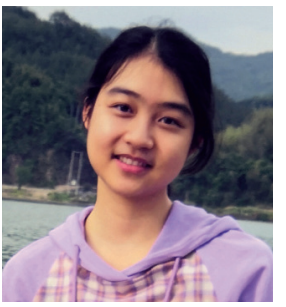

方艺瑾

清华大学心理学系硕士研究生

FANG Yijin

Master Student of Department of Psychology, Tsinghua University

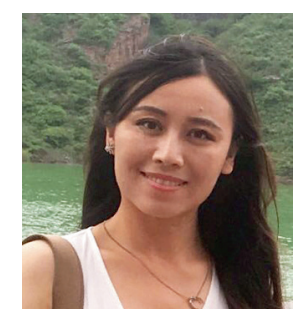

韩西丽

北京大学深圳研究生院城市规划与设计学院副教授

\section{HAN Xili}

Associate Professor of School of Urban Planning and Design, Peking University Shenzhen Graduate School

*Corresponding Author

Address: 160 Chengfu Rd, SanCaiTang Building, Haidian District, Beiijng, Chin

Email: christie@tsinghua.edu.cn
https://doi.org/10.15302/J-LAF-1-030014 收稿时间 RECEIVED DATE / 2020-03-17 中图分类号 / B842.1, TU984.1 文献标怾码 / B
摘要

在设计城市儿童空间时, 一个重要的考量因 素是思考空间将如何助益儿童的成长和学习。大 量认知科学研究表明, 各类基于实证的游戏可促 进儿童的社交、认知和运动能力的发展。本文回 顾了认知和发展科学中有关游戏对学习的裨益的 知识体系, 并鼓励城市设计师对其加以利用。文 若要在城市空间中最大程度地通过游戏促进儿童 学习, 那么设计师应考虑设计的功能可供性— 了相关的认知科学证据, 指出挑战性和模糊性可 以促进儿童的学习和探索性行为, 而挑战性和模 糊性设计可以提升儿童的学习和创造力。再次, 游戏对儿童的社交学习至关重要, 为儿童进行社 交活动创造了机会。城市设计可以通过营造游戏 空间或引入游戏设施一一既包括儿童间的游戏, 也包括亲子游戏一一来激发社会学习。此外, 本 文还结合实际案例说明了基于认知科学的城市空 间的设计过程。

\section{关键词}

城市设计; 儿童; 认知科学; 学习; 游戏 章首先指出了各类游戏可提供的不同学习裨益。 即设计能够激发什么样的游戏。其次，文章梳理

\section{ABSTRACT}

An important consideration in designing urban spaces for children is that it should aid children's development and learning. An extensive literature from Cognitive Science has established that children's social, cognitive, and motor development is promoted by various, wellresearched types of play. This article reviews the body of knowledge from Cognitive and Developmental Science concerning the benefits of play for learning and explains that it can and should be harnessed by urban designers. First, the review shows that different types of play confer different learning benefits. Urban space design that attempts to maximize learning from play should consider design's affordance - what types of play are afforded by the design. Second, evidence from Cognitive Science show that children's learning and exploration are fostered by challenge and ambiguity. Design that embraces these increases learning and creativity. Third, play is critical for children's social learning, as it gives children the opportunity to practice social interaction. Urban design can catalyze social learning by creating spaces and structures that invite play among peers, as well as parent-child play. Beyond this theoretical review, this article also illustrates how to realistically implement these Cognitive Science-oriented urban design with an authentic case study.

\section{KEYWORDS}

Urban Design; Children; Cognitive Science: Learning; Play

\section{基金项目}

洗大学自主科研计划资助项目（项目编号：20197010006)

\section{RESEARCH FUND}

Tsinghua University Initiative Scientific Research Program (No. 20197010006)
译田乐张健肖杰

EDITED BY Tina TIAN TRANSLATED BY Tina TIAN Angus ZHANG XIAO Jie 


\section{1 引言}

城市设计之所以重要的原因之一在于其将直接影响儿童的成长和 发展, 特别是涉及设计的安全性和健康性时。生活在卫生条件较差、

缺乏洁净水源的地区的儿童更容易患病或发育受阻; 而那些生活在治 安水平较差、犯罪多发地区的儿童则面临情绪和心理健康方面的挑 战 ${ }^{[1]}$ 。但是, 健康和安全考量只是儿童友好型城市或城市空间设计的一 方面。本文将基于认知科学和发展科学的视角论证城市环境对儿童学 习的重要影响。

传统的“学习” ( learning) 一般发生在学校的教室里, 从这个意 义上讲, 城市设计和学习有着非常直接的联系。例如, 如果城市中的 学校具有良好的可达性（安全的步行距离或便利的交通）, 那么学校 的人学率和在读率则较高 ${ }^{[2]}$ 。但是认知科学告诉我们, 学习不仅限于学 校教育。儿童在上学之前就开始学习语言 ${ }^{[3] 4]}$, 并且人类大脑最为深刻 的变化也发生于学龄前时期 ${ }^{[5]}$ 。学校并没有明确教给孩子 “朋友” “敌 人” 或其他复杂社会角色的概念, 也没有明确教导他们如何在生活中 发挥创造力以及培养适应能力。那么, 孩子们要在哪里学习此类重要 生活技能呢?

有确切证据表明, 儿童是在游戏中学习到这一切的 ${ }^{[6-18]}$ 。虽然游戏 似乎只是儿童为了好玩而进行的自由活动, 但大量证据表明, 游戏对 于儿童社交、情感和认知方面的发展非常必要。既有文献和经过同行

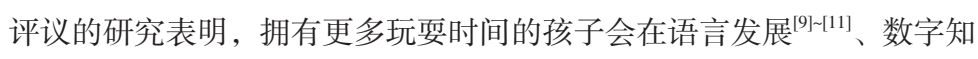
识 ${ }^{[12]}$ 、社交技巧 ${ }^{[13]}$ 和情绪控制 ${ }^{[14[1[1]}$ 方面表现更好。但是, 作为儿童成长 过程的重要一环, 游戏一一尤其是对儿童有益的游戏——不会自然而 然发生，其发生受到周围环境及可供进行游戏的机会的影响。

理想的城市设计会激发更多的游戏活动，从而促进儿童的学习。 例如, 儿童在户外绿地中的游戏频率比在非绿地中更高, 而绿色环境 有助于儿童形成更好的工作记忆 ${ }^{[16]}$ 。本文旨在明确游戏与学习之间的联 系, 进而优化城市设计。例如, 什么样的游戏会激发什么样的学习? 哪些设计会激发最佳游戏行为? 了解游戏与学习之间的认知关联, 有

\section{Introduction}

Urban design matters because it directly impacts children's development. This direct link is most obvious when we think about aspects of design such as safety and health. Children who live in areas with poor access to sanitation and clear water are more susceptible to diseases and their development is stymied; those who live in unsafe, crime-ridden areas face emotional and mental health challenges ${ }^{[1]}$. Designing a child-friendly city or urban space is not limited to issues of health and safety, however. This article highlights evidence from cognitive and developmental sciences, which shows that urban environment also impacts children's learning.

In the most traditional sense of learning - going to school and learning arithmetic in a classroom - the link between urban design and learning is straightforward. For example, cities that provide good access to schools (safe walkable distances or efficient transportation links) have better school enrollment and retention ${ }^{[2]}$. But Cognitive Science informs us that learning is not limited to schooling. Children learn language before they attend school ${ }^{[3][4]}$ and the brain undergoes the most profound changes in the early years of life, prior to schooling ${ }^{[5]}$. School does not teach children explicitly the concepts of friend or foe or other complex social roles, neither does it give explicit instruction on how to be creative and adaptive in life. Where do children learn these and other important life skills?

There is clear evidence that they do so during play ${ }^{[6 \uparrow[8]}$. While play seems to be merely unstructured activities that children do for fun, there is enormous evidence that play is necessary for social, emotional, and cognitive development. Published and peer-reviewed studies have established that children who play more benefit from better language development $t^{[9] \sim[11]}$, improved number knowledge ${ }^{[12]}$, stronger social skills ${ }^{[13]}$ and better emotional contro ${ }^{[14][15]}$. However, as many other things in development, play — especially beneficial play - does not happen automatically; it is influenced by the environment and the opportunities it affords.

An ideal urban design elicits more play activities, which then bring about learning benefits. For example, children play more in outdoor green spaces than in non-green spaces, and the presence of green environments positively correlates with greater working memory ${ }^{[16]}$. This article is to make explicit the link between play and learning as it is relevant in the context of urban design. What kind of play results in what kind of learning, and what designs usher the most beneficial play behavior? By understanding the cognitive link between 
助于城市设计师和政策制定者在城市基础设施的设计中作出明智决 策, 以实现最佳学习效果。

\section{2 可激发儿童游戏的城市设计}

游戏最大的特点是自愿性和自发性。游戏者自发参与游戏，通常 只是单纯地出于好玩的目的 ${ }^{[17]}$ 。这种自愿性和自发性使得孩子成为游戏 的主体, 从而使游戏成为一种高效的学习媒介。但是, 自发性需要催 化, 而物理环境即可充当催化剂的角色, 例如气垫可激发跳跃运动, 房间中的犄角旮昌会激发捉迷藏游戏。作为自发性的催化剂，环境对 于游戏至关重要: 环境为游戏提供了发生场所, 也促进了与环境相适 宜的游戏类型的发生。

也许有人会质疑：为什么要对环境进行设计? 人类身处的所有特 定物理环境不是都能激发游戏的发生吗? 从某种意义上说, 答案是肯 定的：儿童在利用周围环境进行游戏方面的创造力极强。例如, 已为 人父母的读者也许都有这样的经验: 即便婴儿拥有很多精美的玩具, 他们也会从敲打玩具包装盒中获得同样的乐趣。另一方面, 游戏的形 式丰富多样, 儿童可以从各式各样的游戏中获得不同的学习益处：与 同伴一起奔跑嬉闹有助于其肌体发育，而独自安静地玩积木则可以培 养创造力和解决问题的能力。这意味着, 设计可以塑造环境, 使其更 有效地激发儿童的学习能力。换言之, 城市设计是一种通过游戏设置 最大化地提升儿童学习机会的战略手段。

鉴于本文重点关注城市户外环境，故下文将探讨4种能够通过城市 空间设计催生出的户外游戏类型 ${ }^{[18]}$ ：1）机能游戏；2）搭建游戏；3） 扮演游戏; 4 ) 规则游戏。

机能游戏是指儿童进行的有目的/无目的的重复性肌肉运动, 如奔 跑、攀爬、追逐等。这是儿童设施设计中最为常见的游戏类型: 这些 设施为某种特定功能而设计, 例如滑梯可供孩子滑行、秋千可供儿童 摆荡。有时，设施也可同时涵盖多种功能。例如，地面上的石块可供 孩子在上面行走、跨步或跳跃 ${ }^{[19]}$ 。同时，石块的空间排布也可催化出不 play and learning, urban designers and policy makers can make informed decisions about urban infrastructure and optimize them for best learning outcomes.

\section{Urban Design Elicits Play}

Play is characterized by its voluntary and spontaneous nature. The players themselves initiate the play, often doing so without overt goals other than to have fun ${ }^{[17]}$. This voluntary and spontaneous nature is precisely what makes play so effective as a learning medium because the children themselves are the agents of learning. Spontaneity, however, needs catalyzing and physical environment can act as this catalyzer. A bouncy mattress inspires jumping activities; nooks in the house draw children to play hide-and-seek. Environment as a catalyst of spontaneity is critical to play - so that play happens, and so the right type of play happens the most.

A skeptical reader might ask: why need design? All humans live in definite physical environments, do not they all catalyze play? In some sense the answer is yes: children are remarkably creative in making use of whatever they have in their environment to play with. For example, many readers who are parents themselves perhaps recall that despite being surrounded by many great toys, babies seem to find just as much joy in knocking around the cardboard wrappers of their toys. On the other hand, play comes in many forms, which confer various learning benefits. Children who run around playing tag with friends get physical benefits, but a quiet solitary play building blocks also confers benefits of its own, such as creativity and problem-solving skills. Design, then, can shape the environment so that it channels play into its more useful forms. If the aim is to optimize learning opportunities, urban design is a strategic means for achieving it through play.

Because the focus in this article is on urban outdoor environment, we chart four types of play ${ }^{[18]}$ that can be catalyzed by outdoor urban design: 1) functional play, 2) constructive play, 3) pretend play, 4) games with rules.

Functional play is when children do repetitive muscle movement, such as running, climbing, chasing, with or without objectives. This type of play is typically the kind of play that designers have in mind when thinking about child-specific facilities: such a facility is designed for a specific function, for example a slide is for sliding or a swing is for swinging. Sometimes, the design can afford many functions. For example, rocks on the ground can be used for walking, stepping, or jumping ${ }^{[19]}$. The rocks' spatial arrangement, such as spacing distance, can catalyze different play behaviors. For example, the 
同的游戏行为，例如，对于等距排布的石块，大孩子可能只需迈步走 过, 而幼童则需要跳跃才能从一块石头移动到另一块石头之上。

搭建游戏是指利用材料建造事物的游戏, 例如用沙子或水建造 “城堡”。儿童往往会用他们能够获得的可操作道具—包括他们可 以收集、整理、排列的材料一一进行搭建游戏。这些松散的材料即是 搭建游戏的催化剂。例如, 一项研究发现, 当孩子们发现游乐场内有 诸如轮胎和可堆叠的积木这样的材料时, 他们更倾向于进行搭建游 戏; 而当这些材料从游乐场内移走后, 搭建游戏便有所减少 ${ }^{[20]}$ 。

扮演游戏是指儿童运用想象力进行的假想类游戏。例如, 孩子假 装自己是超人、公主或医生等角色, 并代人他们所扮演角色的个性特 征。研究发现, 在封闭空间环境中 (如游戏屋) 扮演游戏更易发生 ${ }^{[20]}$ 。 规则游戏是指在预设的规则下进行的游戏。规则游戏种类繁多, 例如追逐游戏、捉迷藏或打篮球等。诸如体育运动这样的游戏需要特 定的配套设施和设计 (如球场和球网)。此外, 自然和绿地也可催生 出规则游戏, 例如, 相较于毫无特色的人造区域, 儿童更易于在楖林 里玩捉迷藏游戏 ${ }^{[21]}$ 。

\section{3 游戏即学习}

人类发展的一大基本特征是对于新事物一一语言、数字、社会 角色等一一的学习。认知发展研究之父让 - 皮亚杰认为, “游戏即是

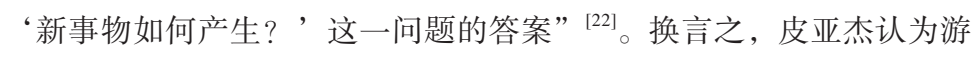
戏对于人类发展发挥着核心作用。然而, 尽管人们普遍认为游戏是一 件好事, 但许多父母和教育者不愿将游戏视为学习。例如, 大多数父 母会因为自己的孩子无法上学而苦恼, 但却很少有父母会因为孩子没 有机会玩要而难过。因此, 游戏通常被认为是 “可以在空闲时间内做 的有趣的事情”, 而不是人类成长和学习的重要方式。的确, 很少有 父母或教育者担心儿童会因缺乏游戏而发育受阻, 然而这种观点是不 可取的。发展科学和认知科学的大量研究表明, 游戏不仅仅是教授性 学习的辅助手段; 相反, 游戏更是一种自我激励型的学习方式。事实 上, 儿童大部分学习成果的获得渠道是游戏, 而非教授性学习。 same distance apart may be walked by the older children, but younger children need to jump across.

Constructive play involves creating things with materials, for example, using sand and water to make a castle. Children tend to do constructive play when they have access to manipulative props - materials that they can pick up, sort, arrange, and collect. These loose materials act as catalyzers for constructive play. For example, one study found that children did more constructive play when loose objects like tire and stackable blocks were available in the playground. When these materials were removed from the playground, children engaged less in constructive play ${ }^{[20]}$.

Pretend play involves imagination and "as-if" thoughts. For example, children pretend to be someone else - superman, a princess, or a doctor - and take up the corresponding personality of their pretend character. Studies found that enclosed spaces, such as playhouses, elicit pretend play ${ }^{[20]}$.

Games with rules are play under prearranged rules. There are many games with rules, like chasing games, hide-andseek, or basketball games. Some games - like sports games need specific facilities and design (e.g., courts, nets). But some games are catalyzed by nature and green spaces, for example, children play hide-and-seek more in the woods than in plain manufactured zones ${ }^{[21]}$.

\section{Play is Learning}

Jean Piaget, widely considered the father of the study of cognitive development, believed that "play is the answer to the question: how does anything new come about?" "22]. Since human development is fundamentally characterized by learning new things - from language to numbers to social roles — Piaget's assertion implies that play is at the very core of development. Yet, despite a widespread belief that play is good, many parents and educators are reluctant to view play as learning. Most parents will be distressed if their children cannot get access to school, but few will lament if their children do not have access to play. Play, then, is often considered "the fun thing you do if you have extra time" and not as an important and critical aspect of one's growth and learning. Indeed, few parents and educators are concerned that children's development will be lacking if they lack play. This thinking is incorrect. Extensive evidence from Developmental and Cognitive Sciences clearly shows that play is not just a side accompaniment to instructional learning. Rather, play is self-motivated learning. In fact, some learning outcomes are mostly accomplished through play and not through instructional learning. 


\section{1 游戏中的学习机制}

本文不仅限于列出游戏对于学习的益处, 而是希望有助于城市设 计师和政策制定者为儿童创造出理想的学习环境。为了深人理解这一 问题, 本文将结合上述 4 种游戏类型讨论通过游戏进行学习, 或将游戏 转化为学习的具体机制。

\subsection{1 机制一: 身体机能的成长与挑战}

机能游戏 (如攀爬墙壁、滑滑梯、荡秋千) 和规则游戏 (追球、 抛接球) 等游戏类型为儿童提供了多种活动身体和锻炼运动技能的机 会。毫无疑问, 任何形式的体育锻炼都有益于人们的身体健康。但 是, 相较于教授情况下的体育锻炼 (如体育课) , 儿童在通过游戏进 行体育锻炼时, 更可能积极地进行这些重复性身体运动。一项研究表 明, 户外活动时间更长的孩子所进行的中高强度体力活动 (一种衡量 体育锻炼强度的标准) 更多, 心肺适能也更高 ${ }^{[23]}$ 。鉴于近年来儿童肥胖 已成为日益严重的城市社会问题, 这一点显得尤其重要 ${ }^{[2]}$ 。一项新近的 后设意见研究显示, 中国儿童和青少年因缺乏体育锻炼而产生了各种 健康问题 ${ }^{25]}$, 而中国儿童体育锻炼的缺乏很可能与他们缺乏游戏活动直 接相关——清华大学脑与智能实验室目前正在积极研究这一问题。如 果研究结果证实了这一假设, 那么城市设计或许将有助于扭转当前儿 童健康的负面趋势, 并发挥重要作用。有趣的是, 很多中国城市敏锐 地意识到了老年人口的健康状况与城市设计之间的联系：许多中国城 市都为老年人配备了大量的免费健身器材。但同时, 中国城市中很难找 到免费的公共游乐场，这与世界上几乎所有其他地区形成了鲜明对比。

游戏除了为儿童创造体能锻炼的机会外, 也对他们的身体机能带 来了挑战。例如, 儿童可能会觉得又高又陡的滑梯极具挑战性, 或者 发觉自己在投掷游戏中总是接球失败。这样的体验可以促使他们了解 自己的机能极限和优势, 而这种认知有助于提升儿童的元学习技能, 使他们能够自信地应对今后的其他挑战。例如, 安 - 拉夫利森等人 ${ }^{[26]}$ 发 现, 与对照组的同龄子亥子相比, 参与冒险性游戏 (如登高类游戏、冲 突类游戏、摔跤类游戏) 达三个月的儿童能在新环境下更快地发现变

\subsection{Learning Mechanisms through Play}

To help urban designers and policy makers in creating environments ideal for learning, we wish to convey more than a list of learning benefits of play. To impart a true understanding of the issue, this article will discuss the specific mechanisms by which play constitutes, or is converted to, learning, involving the four types of play listed above.

\subsubsection{Mechanism 1: Physical Opportunities and Challenges}

Some types of play, such as functional play (such as climbing a wall, sliding down a slide, and swinging) and games with rules (such as running after a ball and play catch) provide plenty of opportunities for children to move their bodies and exercise their motor skills. There is no doubt that doing physical activities of any kind results in better health outcomes. But when children do that through play, they are more likely to initiate and repeat the physical movements, rather than only doing so when instructed, for example in physical exercise lessons. One study shows that children who reported more outdoor play time had higher Moderate to Vigorous Physical Activity (a standard measure of physical activity) and higher cardiorespiratory fitness ${ }^{[23]}$. This evidence is particularly important in urban contexts where child obesity has become a growing problem in recent years ${ }^{[24]}$. A recent meta-review shows a lack of physical activity among Chinese children and adolescents, leading to various health problems ${ }^{[25]}$. It is possible that this lack of physical activities is directly correlated to lack of play among Chinese children — Tsinghua Laboratory of Brain and Intelligence is actively researching this issue at the moment. If this is indeed the case then urban design which elicits play may be instrumental in reversing the current negative trends in children's health. As an interesting side note, Chinese cities are acutely aware of the link between design and health among the elderly population: we see an abundance of free exercise equipment for senior citizens in many areas in urban China. At the same time - in stark contrast to virtually all the rest of the world - it is very challenging to find free public playgrounds in Chinese cities.

Beyond opportunities, play also presents physical challenges. A child may find a high and steep slide challenging or discover that it is difficult to catch a ball in a throwing game. Doing so induces learning about one's own limits and strengths. This awareness often results in meta learning skills that make one confident and adaptive in facing further challenges. For example, Ann Lavrysen et al. ${ }^{[26]}$ found that children who were involved in risky-play activities (e.g., play with great heights, rough and tumble play) for three months were better able than their peers in a control group to detect changes and risks when presented 
化和风险。同样, 在参加充满挑战性的野外活动之后, 孩子们往往表 现出更强的自信心和更好的人际交往能力 ${ }^{[27]}$ 。影响人类成长发展的因素 是相互关联的——运动学习还有助于儿童的情感和社交学习。

\section{1 .2 机制二: 主动探索}

游戏可以激发创造力。以谷歌为代表的公司在办公室设计中注人 俏皮的风格和缤纷明亮的色彩, 希望通过新颖的设计来激发员工的创 造力。那么, 游戏过程是如何激发创造力的? 游戏既是一种主动性的 自我引导行为 ${ }^{[28)-[30]}$ (而非被动性的), 也是一种探索行为 (而非遵循 特定的指示或引导)。当人身处一个新的环境中, 其必然会采用创造 性的方式展开探索 ${ }^{[31][32]}$ 。这一点也体现在儿童的日常游戏中, 例如, 一 岁大的孩子通过按按钮改变屏幕显示内容的方式来探索妈妈的手机。 最终, 积极的探索会促成诱导式学习 ${ }^{[33]}$ : 婴儿探索一段时间后就会知道 按下哪个按钮便能够拍照了! 这种诱导式学习模式可能会促使婴儿进 一步探索世界, 包括对其他物品运作方式的探索。

探索世界的过程中会不断遇到新的问题, 而这通常也促使人们 提出创造性的解决方案。在扮演游戏中, 孩子们必须学会如何 “无中 生有”。例如, 他们在假扮医生时需要创造性地将家用物品当作听诊 器。同样, 在搭建游戏中, 孩子们需要利用有限的可用材料进行创造 性建造。事实上, 既有研究表明, 更多参与扮演游戏或搭建游戏的孩 子往往更具想象力和创造力, 他们在解决问题时往往会别出心裁、另 辟蹊径 ${ }^{[34-[36]}$

那么, 设计如何促进儿童进行积极探索? 认知科学的证据表明, 儿童在模糊陌生的环境下会进行更多的探索 ${ }^{[37[38]}$ 。例如, 当向学龄前儿 童分别展示具有明确因果机制的玩具和模糊机制的玩具时, 他们对后 者的探索时间更长 ${ }^{[37]}$ 。婴儿也会花更长时间来探索他们所遇到的意外情 况 ${ }^{[39]}$ 。了解了这些实证知识后, 设计师便可通过在设计中加人模糊或出 人意料的元素, 来促进儿童开展积极探索。

3.1.3 机制三: 社交互动

儿童必须学习的一项基本生活技能是如何与他人交往。社交是 人类的天性, 一个人的成功在很大程度上有赖于其对自身所处复杂的 人际网络的驾驭能力。但是, 课堂教学无法手把手教授儿童如何开展 with novel situations. Likewise, after participating in a wilderness program full of challenging play, children reported greater selfconfidence and better interpersonal skills $\left.{ }^{[27]}\right)$. Development is interrelated: motor learning also brings about emotional and social learning.

\subsubsection{Mechanism 2: Active Exploration}

Common wisdom holds that play makes one creative. This belief is evident, for example, in companies like Google, which design their offices in playful tones and with kaleidoscopic bright colors, ostensibly to draw out the creative juices of their employees. What exactly happens during play, which fosters creativity? First, play is active and self-directed ${ }^{[28] \sim 30]}$ as opposed to passive; second, it is an exploration as opposed to following instructions or directions. When an individual engages in exploring novel surroundings, he or she is bound to deploy creative ways of proceeding ${ }^{[31][32]}$. This is evident in everyday play situations, such as a one-year-old exploring Mom's phone and pressing buttons to change the phone's display. Eventually, the active exploration results in causal learning ${ }^{[33]}$ : after a while the baby knows what button to press to take a picture! The baby's discovery of a causal structure of the phone may prompt her to make further discoveries about the world, including how other items work.

Explorations of the world inevitably expose new problems that need solving, which often results in creative solutions. In pretend play, children have to solve the problem of "making something out of nothing." For example, they need to creatively use common household objects as stethoscopes when they are pretending to be doctors. Likewise, in constructive play, children think creatively about how to build structures from limited available materials. Indeed, studies show that children who engage more in pretend play or constructive play are more imaginative and creative: they can do more out-of-the box thinking when solving problems ${ }^{[34 \sim[36]}$.

How can design induce active exploration? Evidence from Cognitive Science suggests that children explore more when they are confronted with ambiguous situations ${ }^{[37][38]}$. For example, when preschoolers were shown either a toy that had a clear causal mechanism or a toy with an ambiguous mechanism, they explored the ambiguous toy longer ${ }^{[37]}$. Even infants explore longer when they encounter surprising events ${ }^{[39]}$. We can harness this evidence for design optimization: designs that feature elements of ambiguity or surprise can drive active exploration.

\subsubsection{Mechanism 3: Social Interactions}

One of the most important skills of life that children have to learn is how to interact with others. Humans are social by nature and much of our successes are attributed to how well we 
人际交往，那么孩子们是如何学习与他人沟通、协商、解决分歧、争 论、合作，或说服他人的呢? 我们总是希望孩子能够迅速地掌握所有 社交技能, 那么是否存在学习社交技能的有效途径呢? 研究结果表明, 游戏正是学习这一技能的最好途径。根据心智理论 ( TOM $)^{[40]-[42]}$, 参 与游戏的儿童往往更易于理解他人与自己不同的想法、目标和欲望。 TOM能力对于社交活动至关重要, 如果一个人无法对他人的想法和行 为进行共情和预判, 那么就连简单的日常交流都会变得十分困难这正是自闭症儿童所面临的困境 ${ }^{[3]}$ 。毫无疑问, 通过进行游戏活动, 孩 子可以具备更好的交友及社交能力 ${ }^{[44]}$ 。

游戏之所以能有效地帮助孩子学习社交技能是由于孩子能够在游 戏过程中实践社交方法。不同于界限分明且严格的社会关系环境（如 父母与孩子、教师与学生)，儿童可以在游戏中自由地扮演不同的角 色, 并以相对较低的成本与他人交往。例如, 当孩子假扮成一位母亲 时, 她会尝试站在母亲的角度想象母亲的想法和感受。在多次参与扮 演游戏之后, 孩子会更加擅长换位思考, 学着透过他人的视角来看待 世界 ${ }^{[4]}$ 。这一点在非游戏环境中很难实现, 因为我们绝大多数人 (甚至 包括孩子) 在生活中的角色都是固定的。既有研究也表明，扮演游戏 可以提高儿童的换位思考能力 ${ }^{[46]}$ 。

无论是熟悉或陌生的伙伴, 还是比自己年长或年幼的伙伴, 与不 同的伙伴进行游戏有助于儿童练习社交方法, 调整社交策略。与陌生 的小伙伴进行搭建游戏会锻炼孩子们的沟通和协商能力; 在与比自己 年幼的伙伴玩要时, 孩子们可能不得不做出妥协。吉萨 $\cdot \mathrm{B} \cdot$ 拉马尼 ${ }^{[4]}$ 的研究证明, 参与趣味性和灵活性活动 (而非固定性活动) 的孩子更 愿意与他人沟通, 他们的人际交往能力往往更好。

\section{2 引导性游戏}

有时，儿童的游戏伙伴是成年人，如父母、祖父母或老师，他们 的知识要比孩子多得多。在这样的游戏中, 知识丰富的玩伴可以指导 和支持儿童进行积极探索和发现。这种引导性游戏 ${ }^{[48}[491$ 的关键在于, 成 年人利用其对世界的了解来帮助儿童进行自主学习, 而不是告诉儿童 navigate the complex social networks we live in. Yet this is a subject rarely taught at schools; children do not receive explicit instruction on how to conduct their social transactions. How do children learn to communicate, negotiate, resolve differences, argue, cooperate with or persuade others? By and large, we expect children to learn all these social skills on the go. Is there an effective means to learn social skills? Evidence suggests that play is just the right tool for learning social skills. Children who play have better theory of mind $(\mathrm{TOM})^{[40] \sim[42]}$ - the capacity to understand that others have thoughts, goals, and desires different from our own. TOM is critical for social interactions; it is necessary for us to empathize and anticipate what others will think and do. Without it, even simple everyday communication becomes difficult, as is the case with autistic children ${ }^{[43]}$. Not surprisingly, children who play develop demonstrably better friendships and social competence with peers ${ }^{[44]}$.

The fundamental reason for why play is effective for learning social skills is that it gives children an opportunity to practice social approaches. Unlike in rigid social settings with clear boundaries - parents vs. children, teachers vs. students — play gives children the freedom to take up different roles and to approach social others in a relatively low-cost way. For example, when a child pretends to be the mother, she puts herself in a mother's shoes, imagining what she thinks and how she feels. Over many pretend plays, she becomes more adept in perspective-taking — seeing the world from another's perspective $^{[45]}$. This is difficult to achieve in non-play situations as most of us - even children - have fixed roles in our lives. Indeed, study shows that pretend play increases children's perspective-taking ability ${ }^{[46]}$.

The opportunity to practice social approaches with a variety of play partners - friends, a new child on the playground, older and younger children - allows children to tune their social strategies. During constructive play with strangers children communicate and negotiate; in playing games with younger kids a child may have to make concessions. Geetha B. Ramani ${ }^{[47]}$ found that children who carried out playful and flexible tasks instead of structured ones were more willing to communicate with others; they had the better social interactions.

\subsection{Guided Play}

At times, play partners can also be adults - parents, grandparents, or teachers - who have a lot more knowledge than the child. In such play, the more knowledgeable partner can guide and scaffold children's active exploration and discovery. The key to this guided play ${ }^{[48] 499]}$ is that adults use their better knowledge of the world to help children learn on their own, 
该学些什么。在引导性游戏中, 孩子们可以主动进行自主活动, 而这 些探索行为将在成年人的支持下进行。

引导性游戏之所以有效, 是因为面对世界上纷繁而未知的事物, 父母可以在儿童的探索学习过程中进行激励、询问、暗示或指导, 以 帮助孩子克服阻碍并以更为高效的方式进行学习。例如, 为了认知三 角形的几何类别, 孩子们需要学习三角形的相关知识, 即所有具有三 条边和三个角的图形都是三角形, 且三边不必等长。如果仅告诉儿童 三角形的数学定义, 他们很难对三角形形成认知: 要孩子独自搞明白 哪些图形属于三角形、哪些图形不属于, 需要花费相当长的时间— 单单学习一种几何形状尚且如此, 更不必说孩子们需要学习的其他种种 了。成人可以通过对比的方式帮助孩子进行学习, 例如, 通过把正三角 形与不规则三角形放在一起, 促使孩子们思考二者的相似点和不同点, 这样的比较有助于他们发现三角形的共性 ${ }^{[0]}$ 。实际上, 凯莉 - $\mathrm{R} \cdot$ 费舍 尔等人 ${ }^{[1]}$ 的研究结果表明, 2 3岁儿童在引导性游戏下比说教性教学条 件下的同龄人学习几何图形的效果更好。另一项研究表明, 相较于对 照组儿童, 参加引导性游戏的儿童展现出了更高的运动和物体控制技 能 (如奔跑、跳跃、原地拍球等) ${ }^{[52]}$ 。

引导性游戏还可以激发儿童的探索性行为。例如, 成人可以在扮 演游戏中鼓励孩子不拘一格地使用道具 ${ }^{[53]}$, 或当儿童在挑战性游戏中遇 到问题时暗示他们可能的解决方案。成人还可以通过提问的方式为儿 童提供模糊性或反向性提示 (例如, “我想知道这东西究竟是如何工 作的?”“如果你按下那个按钮, 会发生什么呢? ”) , 从而激发儿 童的探索行为 ${ }^{[54]-[56]}$ 。总而言之, 大量证据表明引导性游戏对学习大有 裨益。由于父母在其中扮演重要角色, 因此引导性游戏通常是最难以 通过设计激发的游戏类型: 父母要么只是简单地给予指示, 要么根本 不参与游戏。后文将介绍如何通过设计激发引导性游戏的具体示例。

\section{3 设计原则小结}

至此, 我们已经获知认知科学领域的相关证据表明游戏能够促进 学习, 也了解了游戏之所以能够促进身体运动、社交和认知发展的机 制。这些机制能够且应该成为城市儿童空间设计的指导原则。在这些 rather than to tell children what to learn. In guided play, the autonomy of the active, self-directed child is preserved, but the exploration is bolstered by others.

Guided play is effective because oftentimes children face a whole barrage of potential hypotheses about how the world works. Parents can prompt, ask, give hints, and otherwise direct the learning process so that children narrow these hypotheses down to the most plausible subset. For example, in order to acquire the geometric category of triangles children need to learn that all figures with three sides and three angles are triangles; the sides do not have to be of equal length. If young children are merely told the mathematical definition of triangles, it will be exceedingly hard for them to learn it. At the same time, discovering on one's own what does and does not count as a triangle takes a really long time. And this is just about one geometric shape, let alone the myriad things children have to learn. Adults can help this learning by presenting the right comparisons to children. For example, when shown typical and atypical triangles together, children are intrigued to think about similarities and differences and this comparison helps them to discover what is common to all triangles ${ }^{[50]}$. Indeed, Kelly R. Fisher et al. ${ }^{[1]}$ found that 2 or 3 -year-olds in the guided play condition learned geometric shapes better than their peers in the didactic condition. In another study, children who participated in guided play improved their locomotor and object-control skills (e.g., running, jumping, doing stationary dribble) compared to those in the control group ${ }^{[52]}$.

Even exploratory behavior can be increased by guided play. For example, adults can prompt children to use objects in novel ways in pretend play ${ }^{[53]}$ or hint at solutions to problems encountered in a challenging game. Adults can also create ambiguous situations or conflicting evidence through questions and prompts ("Hmm, I wonder how this thing actually works?" "What would happen if you press that button?"), which induces children to explore ${ }^{[54]-[56]}$. In sum, a large body of evidence shows that guided play is beneficial to learning. At the same time, guided play is often the most difficult outcome to elicit by design: parents either simply instruct or do not play at all. This article gives concrete examples of how design can induce guided play in later section.

\subsection{Summary of Design Guidelines}

Thus far, we have reviewed the evidence from Cognitive Science showing that play makes learning, as well as the mechanisms by which play benefits motor, social, and cognitive development. We believe that these mechanisms can and should be translated into guidelines for urban design for children. 
基于认知学习机制的经验指南的指导下，城市儿童空间设计将进一步 提升寓教于乐的学习效果。然而, 这些原则并非简单地规定应该或不 应修建哪些设施，而是旨在为设计师提供各类工具及相关概念，以优 化儿童的学习效果。

\subsection{1 功能可供性设计}

游戏的形式多种多样, 每种游戏形式都会带来不同的学习裨益。 因此, 基础设计原则之一就是考虑设计的功能可供性 ${ }^{[57]}$ 。“功能可供 性” ( affordance) 是一项认知科学专业术语, 用于描述环境与使用者 之间的双向关系，即基于使用者的身体条件和其他限制因素，环境能 为使用者提供哪些功能。例如, 椅子对于成年人来说是一个座位, 而 对于婴儿来说则是学步工具, 对于调皮的幼童来说则是攀爬对象。那 么就城市儿童空间设计而言, 我们必须思考: 什么样的设计能够激发 什么样的游戏? 例如, 秋千和滑梯适宜儿童进行机能游戏而非扮演游 戏, 松散材料适合搭建游戏 ${ }^{[20]}$; 封闭空间适合扮演游戏 ${ }^{[20]}$, 而绿地则适 合某些规则游戏 ${ }^{[2]}$ 。抛开具体设计不谈, 优先功能可供性这一设计原则 对于打造具有综合学习效果的空间设计非常有帮助：为了全面提升空 间对于儿童学习的禆益, 设计应考虑多重功能可供性。这一点虽显而 易见，但实际上，我们发现很多游乐场内仅包含机能类游戏设施（秋 千、滑梯、可供孩子骑玩的木制动物/汽车等)，而忽略了其他类型的 游戏。为了提升空间的功能可供性, 设计方案还可以包含适合搭建游 戏的沙坑、适合扮演游戏的小屋, 以及适合捉迷藏的绿地等。

\subsection{2 挑战性设计}

体力挑战性游戏设施能够促进儿童的身体活动, 并鼓励他们进行 适应性和冒险性行为。体力挑战往往表现为儿童遇到了无法实现的目 标, 每到这种时候, 儿童常常会通过反复练习来达成目标——这种解 决问题的能力也是一项重要的认知技能。这意味着, 与其直接设计具 有某种功能的设施 (如通向滑梯顶部的阶梯) , 设计师可以考虑加人 一些体力挑战性设施 (如绳梯)。

挑战性设计中的 “挑战” 在于如何使同一个设施为不同的使用者 提供不同程度的挑战性：绳梯对 2 岁的孩子来说非常具有挑战性，但对 10 岁的孩子来说却相当容易。为了解决这一问题, 设计师可针对不同
We offer such a translation below: rules of thumb informed by cognitive learning mechanisms, by which urban design for children can optimize play-learning benefits. These guidelines do not simply prescribe what should and should not be built; instead, they give tools and a conceptual vocabulary for designers interested in maximizing learning outcomes.

\subsubsection{Affordant Design}

Play comes in several varieties, each of which confers different learning benefits. As such, a fundamental design guideline is to consider the design's affordances ${ }^{[57]}$. Affordance is a Cognitive Science term which captures the bidirectional relation between an environment and users - what the environment offers to users given their bodily and other constraints. For example, a chair provides a sitting place for an adult, but it can be an anchor for an infant learning to walk or a climbing structure for an active toddler. Translating this to children's urban design, we must ask what kinds of designs afford what kinds of play? For example, swings and slides afford functional play but not pretend play while loose materials afford constructive play ${ }^{[20]}$. Enclosed spaces afford pretend play ${ }^{[20]}$ while green spaces encourage some games with rules, though not all ${ }^{[21]}$. Specific designs aside, the guideline of prioritizing affordances is useful if designers want to achieve comprehensive learning benefits: to obtain a gamut of learning benefits the space should feature multiple affordances. This point may seem obvious but, in fact, our observation is that many playgrounds contain facilities only for functional play (swings, slides, wooden animals / vehicles for riding, etc.) and ignores other types of play. A more comprehensive and affordance-centered design would also include, for example, a sandbox for constructive play, a shed for pretend play, some green areas for hide-and-seek, and so on.

\subsubsection{Challenging Design}

Facilities that provide physical challenges catalyze physical activities as well as adaptive and risk-taking behaviors. Physical challenge is also often a form of problem to be solved, so children who encounter them habitually get regular practice in problem-solving skills - an essential cognitive skill. Thus, rather than designing straight functionality (say, a staircase to the top of a slide), designers can instead embed some physical challenge such as a rope ladder.

A "challenge" for challenging design is that one structure may afford different challenges for different users: a rope ladder may be really hard for a two-year-old but easy for a 10 -year-old. One solution is to design a range of structures with different challenges for different age groups; another is to create one 
年龄段的儿童分别设计不同的挑战性游戏设施，也可以在一个游戏设 施内设计多重挑战。例如, 可将绳梯分为两段, 其中一段梯级间距较 小 (对学步幼童颇具挑战性, 但对6 7岁的孩子来说很轻松), 另一段 梯级间距较大, 对大童具有一定的挑战性。当然, 不同年龄段儿童的 游戏方式有时也存在差异 ${ }^{[58)-[60]}$, 但挑战性游戏对所有年龄段的儿童来 说都大有禆益。

\subsection{3 模糊性设计}

认知科学相关证据表明, 模糊性事物更易激发儿童进行积极探 索 ${ }^{[37]-[39]}$, 而此类主动性探索有助于锻炼他们的问题解决能力和创造 力。实现模糊性设计的途径有很多: 例如在草坡背面设置一座滑梯或 一些无法一眼识别其功能的玩具。模糊性设计更适于进行扮演类和搭 建类游戏。例如, 木头或石块等松散材料可提供不止一种功能, 这种 功能上的模糊性有助于激发孩子发挥创造力实现多种搭建。周身有洞 的圆顶小屋也具有功能模糊性（既可以攀爬，也适合捉迷藏），此类 设施可以激发具有挑战性的机能游戏或扮演游戏。

\subsection{4 社交性设计}

游戏还有助于儿童的社交学习, 即通过游戏来锻炼他们的社交技 能。那么, 如何设计可以激发儿童社交活动的空间呢? 首先, 设计师 需要考虑能够促进儿童亲密接触的功能设置及空间距离。秋千显然不 合适一一虽然可以并排设置两三个秋千, 但荡秋千依然是单人游戏活 动。摇摆桥 (三五个人可以一起晃动桥体) 是个不错的选择; 近期一 项研究表明, 诸如摇摆桥之类的集体游戏活动有助于提高学龄前儿童 的协作能力 ${ }^{[61]}$

实现社交性设计的另一种方式是与挑战性设计相结合。设计具有 多重挑战性的游戏设施 (如富于变化的绳梯) 能够促进不同年龄段的 儿童在一起玩要，从而促进孩子间的社交活动。理想状态下，当游戏 设施的挑战性过高时, 年龄较大的孩子会帮助年龄较小的孩子, 从而 形成良好的社交互动。

\section{4 在城市设计中融入认知科学：案例研究}

本文将以一个正在进行中的设计项目为例, 介绍上述认知科学知 识在景观设计实践中的运用。该项目由认知科学与发展心理学者斯黛 structure that affords many levels of challenge. The rope ladder, for example, can have two sections: the left section with small distances between rungs (challenging for toddlers, easy for 6 or 7-year-olds) while the right section with large distances intended to challenge the older children. Of course, children of different ages play somewhat differently ${ }^{[58 \uparrow \sim[60]}$, but children of all ages benefit from challenging play.

\subsubsection{Ambiguous Design}

Evidence from Cognitive Science shows that children actively explore more when they are faced with ambiguity ${ }^{[37] \sim[39]}$. These active explorations result in turn in problem-solving skills and creativity. There are many avenues to design ambiguity, for example, by hiding a slide behind a grassy slope or installing toys with functions that are not obvious at first sight. Some types of play, such as pretend play and constructive play, are more receptive to ambiguity. For example, loose materials like pieces of wood or rocks do not afford just one function and their ambiguity allows them to be constructed into many different things. An igloo-like shed with holes all around is ambiguous (is it to be climbed or to hide inside?). Such structures afford challenging functional play but also pretend play.

\subsubsection{Social Design}

Play confers many social learning benefits because it gives an opportunity for children to practice social interactions. How to elicit social design - design that catalyzes social interactions? First, designers can consider functionality and / or spatial distance that affords physical togetherness. A swing is solitary, though if you put two or three swings side-by-side you can swing together. Even better, perhaps, is a swinging bridge - three or more people can swing the bridge in unison. Interestingly, a recent study shows that swinging together in unison increases preschoolers' cooperative acts ${ }^{[61]}$.

A second way to elicit social design is to incorporate it with challenging design. A structure that affords challenges of many levels, such as a rope ladder with diverse sections, can elicit social interactions, with younger and older children playing together. Ideally, when the challenge gets too hard, older children may help the young ones - a wonderfully beneficial social interaction.

\section{Implementing Cognitive Science in Urban Design: A Case Study}

An ongoing case study described here implements some of the knowledge of Cognitive Science above in a landscape 
拉・克里斯蒂教授和景观设计师韩西丽教授共同完成，二人受委托对 于北京市中心的一处大型户外空间进行了重新设计。目前项目场地上 已有一处儿童活动中心, 但需要进一步提高场地的功能性和支持性, 以促进儿童学习。

基于认知科学的空间设计最重要的一点一也是首要目标一一便 是确立设计目标, 即空间应实现哪些功能。设计师往往会构想出多重 设计目的和多样化的设施设计方案，旨在调和相冲突的设计目标。该 项目主要关注基于认知发育的设计目标, 不过和其他委托项目一样, 项目的设计方案也需要服务于儿童活动中心利益相关方的需求。为了 实现这一点, 项目运用了认知科学原则, 以期实现最有效的循证设 计。换言之, 介绍该设计方案的目的并非要描述一种理想的状态，而 是分享从实际设计过程中总结出的经验：在此过程中, 认知科学原则 的运用必须综合考量外部限制因素和约束条件。

\section{1 目标一: 设计适宜儿童的空间}

这项目标虽然不言而喻, 但在实际操作过程中, 由于涉及多个 利益相关方，目标的沟通和确立却极具挑战性。由于决策者都是成年 人，他们在处理空间问题时往往仅关心成年使用者的利益。例如，设 计儿童活动中心的人口区域时, 项目的利益相关方要求我们设计一个 类似于芝加哥千禧公园 “云门” 的、吸引眼球的装置设施。令人眼前 一亮的设计固然重要, 但是我们还要权衡考量儿童成长的需求: 项目 的空间设计不仅应对儿童具有吸引力, 更要能够促进儿童对空间的 使用。

为了整合视觉体验目标与功能性目标, 项目首先运用了功能可 供性原则。芝加哥 “云门” 装置的功能可供性非常有限——虽然 “云 门” 对成年人来说很有吸引力, 但却没有与儿童用户形成良好互动。 认知科学研究表明, 儿童天生具有好奇心, 当遇到模糊性事物或与既 有认知冲突的事物时, 他们的探索本能便会得到激发 ${ }^{[38]}$ 。为了设计既具 吸引力又能激发孩子探索欲望的空间和设施, 我们需要考虑到儿童的

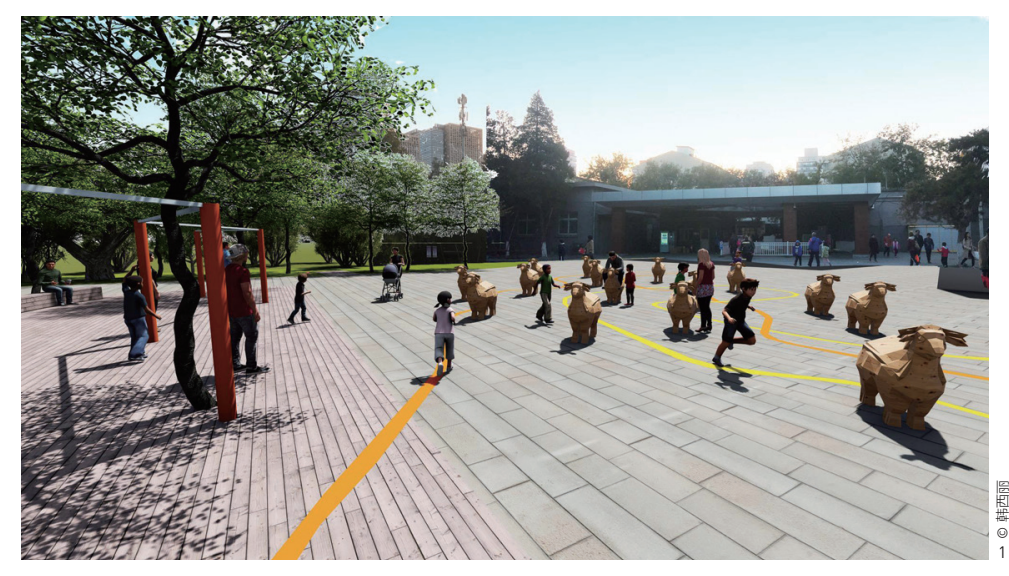

architecture project. This project is a collaboration between Professor Stella Christie (a cognitive scientist and developmental psychologist) and Professor Han Xili (a landscape architect), who were tasked to redesign an existing large outdoor space in central Beijing. This space is currently already occupied by a children's center. However, the space needs a transformation to become more functional and supportive for children's learning.

The most important anchor of Cognitive Science-informed design is to start with the goals. What ends should the space achieve? Designers contend with multiple goals and deliver structures aimed to compromise among many competing objectives. This project focuses on the goals stemming from their understanding of cognitive development. But like any commissioned project, this project also involves goals mandated by the stakeholders of the children's center. The project adapts the Cognitive Science principles to a broader context of these mandated goals, in order to achieve the most effective evidencebased design among all feasible options. That is, the design is not to describe an ideal situation, but rather to share our experience from a real world implementation, in which our desire to apply Cognitive Science principles had to be reconciled with external constraints and mandates.

\subsection{Goal 1: To Design a Space for Children}

This goal may seem obvious, but it is in fact the most challenging one to be communicated and established with various stakeholders of the project. Because decision makers are adults, they tend to view spaces through the lens of adult concerns. As an example, in designing the entrance area to the children's center, we were mandated to create an impressive or imposing structure, with the Chicago Bean given as a benchmark. An inspiring design is certainly an important goal and we would now have to reconcile it with optimizing the benefit for children: the child users should be inspired, and specifically inspired to use the space.

To achieve a synergy between inspirational and functional objectives, first, we considered th guideline of affordant design. The benchmark structure, the Bean, has very limited affordances - it may be inspiring for adults but offers limited interactions to child users. Evidence from Cognitive Science tells us that children are naturally curious and their exploratory instinct is piqued when they encounter objects ambiguous or different from prior beliefs ${ }^{[38]}$, viz. ambiguous design guideline. As such, to design space and facilities that are both inspiring and inviting to be explored, we need to consider children's existing knowledge: what do children know and recognize? The kind of ambiguous appearance that elicits children's exploration may be most easily achieved by starting
1. 项目运用儿童熟悉的动物 形象 (羊), 并结合模糊 性的空间设计, 以激发 儿童的好奇心和探索欲 (设计: 韩西丽)。

1. Using familiar animals (sheep) in ambiguous spatial configuration to evoke children's curiosity and exploration (Designed by Han Xili). 
(1) 该博物馆是一个典型 的寓教于乐空间，不 包含在本项目的设计 范畴之内。

(2) 魔法坚琴装置由Jen Lewin艺术设计工作 设计。该工作室壇长 设计。该工作室擅长 利用互动性灯光和音 效艺术创建大型公共 装置。

1) The museum is an exemplary play-based learning space that learning space that is not part or this renovation project. The installation Magical Harps was designed by Jen Lewin Studio, an interactive light and sound artist building large scale public instal
现有知识水平：孩子们知道、能够辨别出什么? 鉴于模糊性观感能够 有效激发孩子的探索欲，制造模糊性最简单的方法是以一种全新的方 式呈现那些已为孩子们所熟知的元素。但如果设计引入的是成年人熟 知的、基于成年人视角的 “新颖” 元素, 那么最终的设计成果则不会 激发儿童的探索欲望。

根据这一原则, 韩教授提出引人木质羊群的设计：各个年龄段的 儿童都对羊这种动物很熟悉, 但项目采用了一种新颖的羊群排布方法 (图1), 这对于孩子们来说是陌生的。此外, 羊群的空间排布也体 现出了一种行为/互动上的模糊性: 这些木羊既好像朝着同一个方向奔 跑, 又像是在相互追逐。这种模糊性有助于激发孩子的探索性行为: 他们可以骑在羊身上 (玩扮演游戏), 也可以在羊群间追逐嬉戏, 还 可供他们以木羊为道具进行规则游戏 (如跳绵羊比赛)。孩子们不仅 会使用这些设施, 还会与木羊进行充满想象力和创造力的互动。“云 门”装置虽然非常吸引眼球，但却无法带来此类效果。

\section{2 目标二: 设计适合亲子互动的空间}

促进社交活动, 特别是亲子互动, 是本项目的出发点。一位项目 利益相关者指出，陪同子女来到儿童活动中心的父母往往不会参与孩 子们的活动。即便去旁边陈列着诸多触碰类游戏设施的儿童博物馆 ${ }^{(}$, 很多父母也只是坐在一边, 不与孩子互动。孩子会因此错失很多学习 机会, 因为大量研究表明, 引导性游戏能够极大地促进儿童学习。父 母和看护人（如祖父母和老师）通过提问、引导，甚至只是简单的交 流，即可帮助孩子获得寓教于乐的学习。例如，父母可以在扮演游戏 中充当游戏伙伴，也可以鼓励孩子勇敢面对机能游戏中的挑战（如爬 得更高，或尝试更具挑战性的滑梯）。

经观察发现, 很多家长存在共同参与游戏的心理障碍：在他们看 来, 儿童空间太幼稚, 只能被儿童使用。为了带动父母参与引导性游 戏, 设计应该突破这种认知障碍, 引人能够唤醒成年人的好奇心和探 索欲的游戏设施，并运用能够激发孩子探索欲的模糊性元素来激发成 年人的参与兴趣。美国帕洛阿尔托市魔法大桥游乐场的 “魔法竖琴” (2) with familiar concepts and re-purposing them in novel ways. But if the design begins with a concept familiar to adults, and reworks it in a way that seems novel to adults, it will not induce children to explore.

Using this principle, Prof. Han proposed a design using wooden sheep - familiar animals for children across a wide range of ages - but arranged the herd in a spatial configuration unfamiliar to children (Fig. 1). While static, the spatial configuration of the sheep gives a perception of action and interaction. Furthermore, the action / interaction appears ambiguous - the sheep can be perceived as running together towards a common destination or chasing each other. Such ambiguity invites exploration from children: they can hop on the sheep riding them (pretend play) or do various runs between the sheep. There is a potential for a game with rules with the sheep as props, e.g., a racing game where you have to jump over every other sheep that you pass. Children will not only be enticed to use these structures, they also learn to be imaginative and creative in their interactions with the sheep. Impressive as it is, the Chicago Bean alone does not induce this behavior.

\subsection{Goal 2: To Design Space that Elicits Parent-Child Interactions}

Social interaction, in particular parental interaction and involvement in children's activities, is the original mandate of this project. One of the project's stakeholders noticed that parents visiting the children's center often stayed uninvolved in their children's activities. Even when visiting the neighboring, excellent children's museum ${ }^{(1)}$ which is rife with enticing touchand-play infrastructure, many parents just sat on the side, not interacting with their children. This is a missed learning opportunity because, as we have seen in a large number of studies, guided play is extremely beneficial for children's learning. Through questions, guidance, even just sheer communicative exchanges, parents and caregivers (grandparents or teachers) can engage children in playful learning interactions. For example, parents can be the play partner in a pretend play, or they may encourage the child to take up challenges in a functional play (to climb higher or to try a more difficult slide).

Our observations reveal a psychological barrier in that many adults think that kids' space is only for kids - it looks infantile and should be used by children only. To entice parental involvement and to result in guided play, the design can break perceived barriers with structures that awaken adults' curiosity and taste for exploration. The elements of ambiguous design that enhance children's exploration can also be deployed to awaken adults' desire to play. A great example of such a design is the Magical Harps ${ }^{2}$ installed at the Magical Bridge Playground, 
装置便是一个很好的例子。该装置的主体是一个由金属拱架构成的 “24弦坚琴”（图2），当有人从拱架下经过或移动（变换身体姿势、

跳、跑等) 时, 坚琴便会发出美妙的音乐。这个装置设计简单但却可 以发出声响, 成年人也会为之吸引, 好奇装置的发声原理。克里斯蒂 教授经过观察发现, 家长会自然而然地参与其中, 与孩子们一起探索 装置的工作原理。魔法坚琴的成功还在于其运用了社交性设计原则: 这一游戏设施可供不同的人群同时使用, 当很多人一起在拱架下玩要 时, 坚琴便会演奏出一曲 “交响乐”。这一集体游戏方式既有趣又具 互动性, 对孩子和家长来说都是一种学习体验。在我们的设计方案中 也可以引人类似的游戏设施, 并融人京剧乐器等中国语境元素。

带动父母和孩子们一起游戏的另一方式是运用空间邻近性。空间 上的邻近可以促进心理上的亲近：当距离孩子较近时，父母更容易与 孩子进行互动。很多游乐场所周边都设有长登, 在孩子玩要期间, 父 母往往只是坐在一旁, 不参与孩子的活动。而本项目建议在游戏区域 内部设计休䕀设施。例如, 我们在一处区域内部设计了一条东西向的 长登, 并以长発为中轴线, 南北两侧均为游戏空间。家长既可以在长 登上休息, 也可以随时加人到孩子的游戏中去。同时, 孩子们也可以
Palo Alto, the United States. This installation is a 24-string-laser harp encased in a metal arch (Fig. 2) that can be activated by moving underneath it, including gesturing, jumping, or running. Because the arch is simple-looking but produces music, adults are intrigued to play with it and try to figure out what actually produces the music. During Professor Christie's observations, parents were naturally enticed to play with the musical harp and they often conversed with their children to figure out how the magical harp worked. Through its functionality, the Magical Harps has also incorporated the guideline of social design - a single structure that invites many types of users to play together. When many bodies moved underneath the harp, the resulting play was an orchestra-like music. Playing together is fun and interactive; it is a learning experience for children and adults alike. In our design, we proposed to implement a structure similar to the Magical Harps but modified to the Chinese context - for example by using sounds from Beijing opera's musical instruments.

A second way to invite parental involvement in children's play is by using spatial proximity. Spatial proximity increases psychological proximity: it is obviously easier to interact with your child if you are nearby. In many playgrounds benches are placed on the periphery, which makes parents to sit aloof, unengaged with children's activities. In our design, we proposed to place resting structures within the play area. For example, in one area we designed a long sitting bench along the east-west line. There are play areas both to the north and south of the bench, so our placement made the bench into a central axis of the play space. Parents can rest but they can also easily interrupt their resting to take part in their children's play. At the same time, children can hop on the bench or jump through it. Such spatial proximity encourages closer interactions between parents
2. 魔法坚琴是一个很好的 案例：其可供成人和儿 童一同玩要、探索, 在 游戏过程中促进了亲子 互动。

2. Magical Harps is an example of a structure that invites both adults and children to play and explore, increasing social interaction parents and children during play.
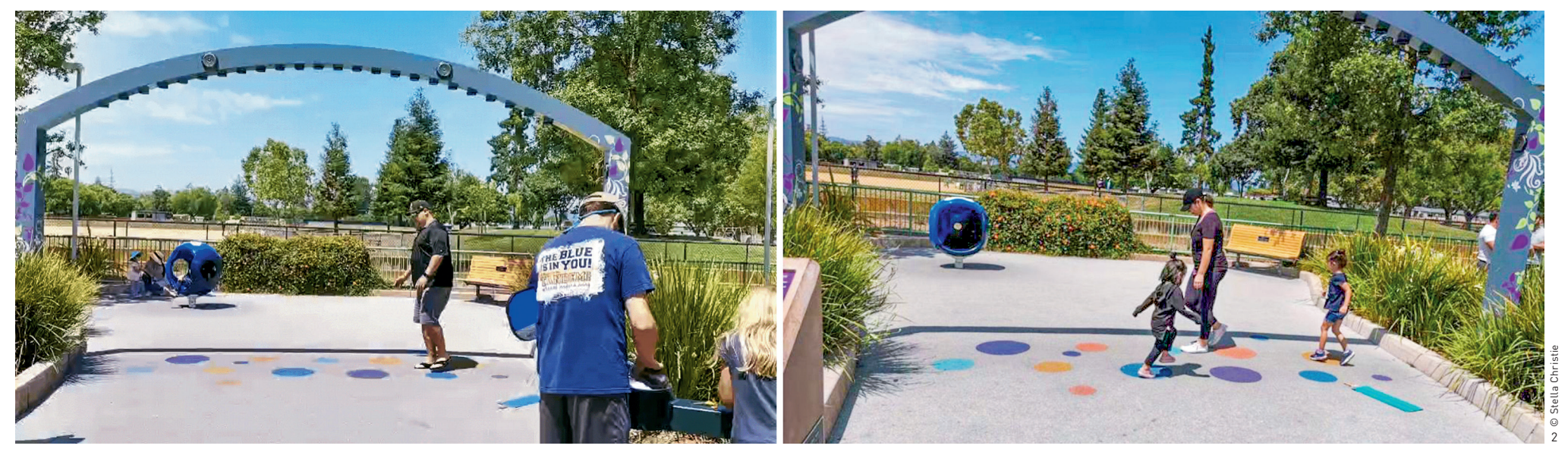
3. 火山游戏设施具有不同 的攀爬难度, 可供不 同年龄段的孩子一起玩 要, 能够锻炼儿童的社 交和情绪管理能力 ( 设 计: 韩西丽)。

3. A "volcano" structure whose topology provides varying levels of climbing challenges, inviting children of all ages to play together, fostering children's tearing of sociat learing social (Designed by Han Xili).

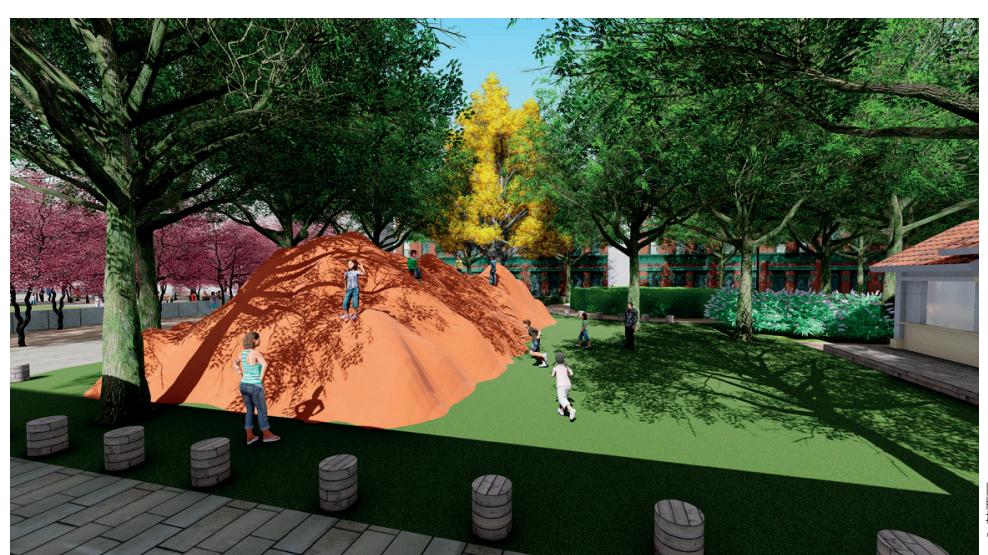

围绕长登跳上跳下，或翻越到长登的另一侧。这种空间邻近性既能增 加亲子互动，又为看护人提供了必要的休息空间。

\section{3 目标三: 德育}

利益相关方希望项目设计可以服务于儿童活动中心的德育目标, 并指出这一目标与亲子互动目标之间的区别。亲子互动目标旨在促进 父母通过引导性游戏方式参与儿童活动，而并非让父母对儿童进行教 育。利益相关方希望通过具体设计措施（如宣导展板或展览）对孩子 进行品德价值观教育。

和利益相关方一样, 我们也认为德育对孩子的成长非常重要。 但从认知科学角度来说, 说教并不是最有效的促进品德价值观学习的 方式; 相较于被动式学习, 主动性学习更有助于孩子的道德发展。首 先, 单纯从设计用途角度来说, 主动性学习更适合本项目, 因为项目 设计的是户外空间（而非教室）, 户外空间能够非常好地促进儿童的主 动性探索。其次, 认知科学相关证据表明, 主动性学习的泛化效果 (孩 子会将其所学运用于其他场景之中) 更佳, 且学习效果更持久 ${ }^{[62 \mid[63]}$, 尤 其适用于学习品德等复杂的抽象概念。我们显然希望孩子习得的品德 知识能够受用终生, 而不仅限于一时一地。在本项目中, 我们没有仅 仅通过设计精美的展板向孩子宣传乐于分享、诚实守信等美德，而是 通过设计激发儿童 (或其他学习者) 依靠他们自己的道德判断来主动 地获取信息、提出问题并解决问题。

那么, 如何鼓励主动性品德学习呢? 认知科学相关证据表明, 儿 童和他人一起游戏能够锻炼孩子们的亲社会行为 (如何分享、如何协 调差异、如何合作等), 这些行为将为儿童一生各个层面的品行奠定 基础。为了增加儿童的社交机会, 我们结合了挑战性设计和社交性设 计原则，设计了具有不同挑战性的游戏设施，让不同年龄段的孩子一 起游戏。例如，韩教授提出了一种 “火山”游戏设施（图3），这种设 and children, but it also recognizes the reality that adult caregivers often need to take a break from actively caring for their children.

\subsection{Goal 3: Moral Education}

The stakeholders stated as their main goal that the children's center provide moral education for children. The stakeholders view this goal as distinct from the goal for parentchild interactions that aims at increasing parental involvement in children's play, i.e. to increase Guided Play, but not for the parents to teach the children. Stakeholders who mandated the goal for moral education believe that children need to be taught moral values through explicit design, for example, using educational boards or exhibitions containing moral teachings.

We share the stakeholders' view that moral education is important for child development. However, Cognitive Science informs us that such direct instruction about moral values is not the most effective means of learning. Instead, active learning, rather than passive instruction, benefits children's moral development more strongly. First, purely from a design usage perspective, active learning makes sense: we are designing not classrooms but outdoor spaces, which afford active explorations best. Second, evidence from Cognitive Science shows that active learning results in better generalization (children apply what they learn to more situations) and a longer retention of benefit ${ }^{[62][63]}$. This kind of outcome is particularly desirable for learning complex concepts like morality. Clearly, we want children to be able to use their moral knowledge in a variety of situations throughout their lifetime, not limited to the here and now. We will not achieve this outcome merely by designing instructional boards telling children the values of community sharing or honesty, even when these good words are inscribed in beautiful designs. The design must encourage children (any learners) to actively gain information, ask questions, or solve problems requiring moral judgement.

How to elicit active moral learning? Evidence from Cognitive Science shows that when children play with others, they have to practice prosocial behaviors (to share, to reconcile differences, to cooperate, etc.) which builds an intrinsic moral foundation applicable to the full spectrum of life situations. To provide social approach opportunities, we combine guidelines of challenging design and social design and design play structures with varying levels of challenges to invite children of many ages to play together. For example, in one design Prof. Han proposed a "volcano" structure (Fig. 3) whose topography provides varying levels of climbing challenges. The younger 
施具有不同的攀爬难度。年龄较小的孩子可以爬到 “火山”中部，大 一些的孩子可以快速地冲到 “火山” 顶部。这些活动发生在同一空间 内, 这种空间邻近性能够促进儿童的社交活动。例如, 当看到别人遇 到困难时, 擅长攀爬的孩子可能会伸出援手, 这就段炼了儿童帮助他 人和传达善意的能力。同样, 在讨论问题的解决办法的过程中, 儿童 的沟通合作能力也会得到锻炼。此外, 不同于学校环境, 户外游戏中 的小伙伴是不固定的，大家彼此间也不熟悉，这将有效锻炼孩子们的 问题解决能力和社交技能, 并且这种变化的游戏情景有助于儿童不断 地践行他们的品行标准。

\section{5 结论}

城市环境对于包括儿童在内的城市居民的身心健康具有重要影 响。认知科学和发展心理学的相关研究表明, 设计不仅会影响健康和 安全等基本福祉, 还会对儿童的学习能力和发展水平产生深远影响。 城市设计能够激发儿童的游戏热情, 儿童能够通过游戏来了解世界, 学习那些传统课堂上不教授的知识。因此, 有助于激发儿童游戏热情 的城市空间设计能够为孩子创造宝贵的学习机会, 使其更健康、更具 创造力, 并更好地融人社会。如果一座城市缺乏游戏机会, 那么它也 剥夺了儿童通过游戏进行学习的机会。

如果孩子代表未来，那么城市设计师和政策制定者在为孩子创造 尽可能多的学习机会方面肩负着重大责任。通过明确了解游戏对于学 习的作用机制, 城市建设者可将相关知识运用于设计决策的过程中。 本项研究希望能够进一步加强所有利益相关方 (政策制定者、设计 师、认知学者、教育工作者和父母 ) 之间的合作, 打造有助于儿童可 进行充分学习的城市设计。LAF

\section{致谢}

第一作者感谢巴特洛梅耶・杰科对文本提供的有益的思路讨论。 children can climb up to a middle level while the older ones can try running fast to the top. But because the activities take place in one space, social interactions are guaranteed through spatial proximity. For example, seeing that others have climbing difficulties, a good climber may give his / her hand to pull the less able climbers, practicing help and kindness. These challenges also translate to problem solving situations; in discussing how to solve problems together, children practice their communication and cooperation skills. Furthermore, unlike within-school interactions where children already know each other, outdoor play such as this presents problem solving and social approach opportunities with different players every time. This prepares children to exercise their moral intuitions in wider-ranging real life situations.

\section{Conclusion}

There is no doubt that urban environment has a significant impact on the well-being of its inhabitants, including children. Analysis of evidence from Cognitive Science and Developmental Psychology clearly shows that design not only impacts basic well-being such as health and safety, but that it can shape children's learning and development. Urban design can catalyze play - a critical mechanism by which children learn much knowledge about the world, including knowledge that is not explicitly taught in traditional instructional settings. Consequently, cities that catalyze play foster critical learning opportunities for its child inhabitants so they become healthier, more creative, more adept social players. Cities that lack play opportunities deprive children of these learning benefits.

If children are the future then urban designers and policy makers have a great responsibility to furnish learning opportunities whenever possible. By understanding the precise mechanisms by which play brings about learning, city builders can use evidence-based information in their decision-making about design. We hope this review gives impetus to future collaborations between all stakeholders - policy makers, designers, cognitive scientists, educators, and parents - to create urban designs that maximize learning for children. LAF

\section{ACKNOWLEDGEMENT}

The first author expresses gratitude to Bartlomiej Czech for discussions on ideas put forward in this article. 
[1] UNICEF. (2012, March 1). The State of the World's Children 2012: Children in an Urban World. Retrieved from http:// www.unicef.org/sowc2012/pdfs/SOWC-2012-Main-Report EN 21Dec2011.pdf

[2] Stein, M. L., \& Grigg, J. A. (2019]. Missing bus, missing school Establishing the relationship between public transit use and student absenteeism. American Educational Researc Journal, 56(5), 1834-1860.

[3] Bloom, P. (2002). How children learn the meanings of words. Cambridge: MIT press.

[4] Pinker, S. (2003). The language instinct: How the mind create language. London: Penguin UK.

[5] Kuhl, P. K. (2000). Language, mind, and brain: Experience alters perception. The New Cognitive Neurosciences, (2), 99 115.

[6] Hirsh-Pasek, K., Golinkoff, R. M., \& Eyer, D. (2004). Einstein never used flash cards: How our children really learn - and why they need to play more and memorize less. New York: Rodale Books.

[7] Piaget, J. (1962). Play, dreams, and imitation in childhood (G. Gattegno \& F. M. Hodgson, Trans.). New York: Norton.

8] Vygotsky, L. S. (1967). Play and its role in the mental development of the child. Soviet Psychology, 5(3), 6-18

9] Tamis-LeMonda, C. S., Shannon, J. D., Cabrera, N. J., \& Lamb, M. E. (2004). Fathers and mothers at play with their 2-and 3-year-olds: Contributions to language and cognitive development. Child Development, 75(6), 1806-1820.

[10] Lillard, A. S., Lerner, M. D., Hopkins, E. J., Dore, R. A., Smith E. D., \& Palmquist, C. M. (2013). The impact of pretend play on children's development: A review of the evidence. Psychological Bulletin, 139(1), 1-34.

[11] Neuman, S. B., \& Roskos, K. (1992). Literacy objects as cultural tools: Effects on children's literacy behaviors in play. Reading Research Quarterly, 27(3), 202-225.

[12] Sarama, J., \& Clements, D. H. (2009). Building blocks and cognitive building blocks: Playing to know the world mathematically American Journal of Play, 1(3), 313-337.

13] Rubin, K. H. (1980). Fantasy play: Its role in the development of social skills and social cognition. New Directions for Child and Adolescent Development, 1980(9), 69-84.

[14] Hillman, C. H., Pontifex, M. B., Castelli, D. M., Khan, N. A. Raine, L. B., Scudder, M. R., ... Kamijo, K. (2014). Effects of the FITKids randomized controlled trial on executive control and brain function. Pediatrics, 134(4), e1063-e 1071

[15] Pagani, L. S., Fitzpatrick, C., Archambault, I., \& Janosz, M. (2010). School readiness and later achievement: A French Canadian replication and extension. Developmental Psychology, 46(5), 984-994.

[16] Dadvand, P., Nieuwenhuijsen, M. J., Esnaola, M., Forns, J., Basagaña, X., Alvarez-Pedrerol, M., ... Jerrett, M. (2015). Gree spaces and cognitive development in primary schoolchildren. Proceedings of the National Academy of Sciences, 112(26). 7937-7942.

[17] Smith, P. K., Takhvar, M., Gore, N., \& Vollstedt, R. (1985). Play in young children: Problems of definition, categorisation and measurement. Early Child Development and Care, 19(1-2). 25-41.

[18] Smilansky, S. (1968). The effects of sociodramatic play on disadvantaged children. New York: Wiley.

[19] Prieske, B., Withagen, R., Smith, J., \& Zaal, F. T. (2015). Affordances in a simple playscape: Are children attracted to challenging affordances? Journal of Environmental Psychology, (411), 101-111.

[20] Maxwell, L. E., Mitchell, M. R., \& Evans, G. W. (2008). Effects of play equipment and loose parts on preschool children's outdoor play behavior: An observational study and design intervention. Children Youth and Environments, 18(2), 36-63.

[21] Zamani, Z. (2016). 'The woods is a more free space for children to be creative; their imagination kind of sparks out there': Exploring young children's cognitive play opportunities in natural, manufactured and mixed outdoor preschool zones. Journal of Adventure Education and Outdoor Learning, 16(2), 172-189.

[22] Elkind, D. (2008) The power of play: Learning what comes naturally. American Journal of Play, 19(1-2), 1-6.

[23] Schaefer, L., Plotnikoff, R. C., Majumdar, S. R., Mollard, R. Woo, M., Sadman, R., \& Veugelers, P. (2014). Outdoor time is associated with physical activity, sedentary time, and cardiorespiratory fitness in youth. The Journal of Pediatrics, 165(3), 516-521.

[24] Commission on Ending Childhood Obesity of World Health Organization. (2016). Report of the commission on ending childhood obesity. Retrieved from https://www.who.int/endchildhood-obesity/publications/echo-report/en/

[25] Lu, C., Stolk, R. P., Sauer, P. J., Sijtsma, A., Wiersma, R., Huang, G., \& Corpeleijn, E. (2017). Factors of physical activity among Chinese children and adolescents: A systematic review. International Journal of Behavioral Nutrition and Physical Activity, 14(1), 23-34.

[26] Lavrysen, A., Bertrands, E., Leyssen, L., Smets, L. Vanderspikken, A., \& De Graef, P. (2015). Risky-play at school. Facilitating risk perception and competence in young children. European Early Childhood Education Research Journal, 25(1). 89-105.

[27] Kaplan, R. (1977). Summer outdoor programs: Their participants and their effects. Children, nature, and the urban environment: USDA Forest Service General Technical Report NE-30, 175-179.

[28] Carey, S. (2009). The Origin of Concepts. Oxford: Oxford University Press.

[29] Chi, M. T. H. (2009). Active-constructive-interactive: A conceptual framework for differentiating learning activities. Topics in Cognitive Science, 1(1), 73-105.

[30] Xu, F., \& Kushnir, T. (2012). Advances in child development and behavior: Rational constructivism in cognitive development. Waltham: Elsevier

[31] Cook, C., Goodman, N. D., \& Schulz, L. E. (2011). Where science starts: Spontaneous experiments in preschoolers exploratory play. Cognition, 120(3), 341-349.

[32] Van Schijndel, T. J., Visser, I., Van Bers, B. M., \& Raijmakers, M. E. (2015). Preschoolers perform more informative experiments after observing theory-violating evidence. Journal of Experimental Child Psychology, (131), 104-119.

[33] Gopnik, A., Glymour, C., Sobel, D., Schulz, L., Kushnir, T., \& Danks, D. (2004). A theory of causal learning in children: Causal maps and Bayes nets. Psychological Review, 111(1), 1-31.

[34] Wallace, C. E., \& Russ, S. W. (2015). Pretend play, divergent thinking, and math achievement in girls: A longitudinal study. Psychology of Aesthetics, Creativity, and the Arts, 9(3), 296-

[35] Hoffmann, J., \& Russ, S. (2012). Pretend play, creativity, and emotion regulation in children. Psychology of Aesthetics, Creativity, and the Arts, 6(2), 175-184.

[36] Hoffmann, J. D., \& Russ, S. W. (2016). Fostering pretend play skills and creativity in elementary school girls: A group play intervention. Psychology of Aesthetics, Creativity, and the Arts, 10(1), 114-125

[37] Schulz, L. E. \& Bonawitz, E. B. (2007). Serious fun: preschoolers engage in more exploratory play when evidence is confounded. Developmental psychology, 43(4), 1045-1050.

[38] Bonawitz, E. B., Van Schijndel, T. J., Friel, D., \& Schulz, L. (2012). Children balance theories and evidence in exploration, explanation, and learning. Cognitive Psychology, 64(4), 215234

[39] Stahl, A. E., \& Feigenson, L. (2015). Observing the unexpected enhances infants' learning and exploration. Science, 348(6230), 91-94.

[40] Goldstein, T. R., \& Winner, E. (2011). Engagement in role play, pretense, and acting classes predict advanced theory of mind skill in middle childhood. Imagination, Cognition and Personality, 30(3), 249-258.

[41] Qu, L., Shen, P., Chee, Y. Y., \& Chen, L. (2015). Teachers' Theory-of-mind Coaching and Children's Executive Function Predict the Training Effect of Sociodramatic Play on Children's Theory of Mind. Social Development, 24(4), 716-733.

[42] Weisberg, D. S. (2015). Pretend play. Wiley Interdisciplinary Reviews: Cognitive Science, 6(3), 249-261.
[43] Tager-Flusberg, H. (1992). Autistic children's talk about psychological states: Deficits in the early acquisition of theory of mind. Child Development, 63(1), 161-172.

[44] Pellegrini, A. D., Kato, K., Blatchford, P., \& Baines, E. (2002) A short-term longitudinal study of children's playground games across the first year of school: implications for social competence and adjustment to school. American Educational Research Journal, 39(4), 991-1015.

[45] Kostelnik, M. J., Soderman, A. K., Stein, L. C., \& Whiren, A. P. (1993). Guiding Children's Social Development. New York: Delmar Publishers Inc

[46] Burns, S. M., \& Brainerd, C. J. (1979). Effects of constructive and dramatic play on perspective taking in very young children. Developmental Psychology, 15(5), 512-521.

[47] Ramani, G. B. (2012). Influence of a playful, child-directed context on preschool children's peer cooperation. MerrillPalmer Quarterly, 58(2), 159-190.

[48] Weisberg, D. S., Hirsh-Pasek, K., Golinkoff, R. M., Kittredge, A. K., \& Klahr, D. (2016). Guided play: Principles and practices. Current Directions in Psychological Science, 25(3), 177-182.

[49] Hirsh-Pasek, K., Adamson, L. B., Bakeman, R., Owen, M. T., Golinkoff, R. M., Pace, A., ... Suma, K. (2015). The contribution of early communication quality to low-income children's language success. Psychological Science, 26(7), 1071-1083.

[50] Christie, S., \& Gentner, D. (2010). Where hypotheses come from: Learning new relations by structural alignment. Journal of Cognition and Development, 11(3), 356-373.

[51] Fisher, K. R., Hirsh-Pasek, K., Newcombe, N., \& Golinkoff, R. M. (2013). Taking shape: Supporting preschoolers' acquisition of geometric knowledge through guided play. Child Development, 84(6), 1872-1878.

[52] Palma, M. S., Pereira, B. O., \& Valentini, N. C. (2014). Guided play and free play in an enriched environment: Impact on motor development. Motriz: Revista de Educação Física, 2012 . 177-185.

53] Van Schijndel, T. J. Singer. E., Van der Maas, H. L., \& Raijmakers, M. E. (2010). A sciencing programme and young children's exploratory play in the sandpit. European Journal of Developmental Psychology, 7(5), 603-617.

[54] Bonawitz, E., Shafto, P., Gweon, H., Goodman, N. D., Spelke, E., \& Schulz, L. [2011). The double-edged sword of pedagogy: Instruction limits spontaneous exploration and discovery. Cognition, 120(3), 322-330.

[55] Kittredge, A. K., Klahr, D., \& Fisher, A. V. (2013, October). Show and tell: The effect of instruction on discovery. Paper presented at the Biennial Meeting of the Cognitive Development Society, Memphis, TN.

[56] Sobel, D., \& Sommerville, J. (2010). The importance of discovery in children's causal learning from interventions. Frontiers in Psychology, (1), 176-183.

[57] Gibson, J. J. (1979). The ecological approach to visual perception. Boston: Houghton Mifflin.

[58] Pellegrini, A. D. (2002). Rough-and-tumble play from childhood through adolescence: Development and possible functions. In P. K. Smith, \& C. H. Hart (Eds.). Blackwell handbook of childhood social development (pp. 438-453). Oxford/Malden, Mass.: Blackwell Publishers.

[59] Pellegrini, A. D., \& Smith, P. K. (Eds.). (2005). The nature of play: Great apes and humans. New York: Guilford Press.

[60] Zelazo, P. R., \& Kearsley, R. B. (1980). The emergence of functional play in infants: Evidence for a major cognitive transition. Journal of Applied Developmental Psychology, 1(2) 95-117.

[61] Rabinowitch, T. C., \& Meltzoff, A. N. (2017). Synchronized movement experience enhances peer cooperation in preschool children. Journal of Experimental Child Psychology, (160), 21-32.

[62] Gureckis, T. M., \& Markant, D. B. (2012). Self-directed learning: A cognitive and computational perspective. Perspectives on Psychological Science, 7(5), 464-481.

[63] Schulz, L. (2012). The origins of inquiry: Inductive inference and exploration in early childhood. Trends in Cognitive Sciences, 16(7), 382-389. 